Jusmal llmial

PFUR AT DE

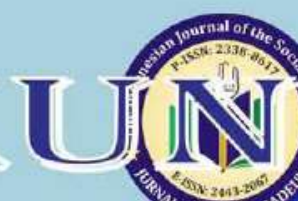

Vol. 5, No. 3, September 2017

$\int_{\substack{\text { Indrjesident } \\ \text { si in }}} 1$

sCAD Intependent Acreditatiou by 100 since 2014 $\bigodot$ Copernicus Publications

\section{JIP}

The Indonesian Journal of the Social Sciences www.journal.scadindependent.ors D01 Prefix Number; 10,26811
Csinta

INDEX COPERNICUS 


\title{
THE CHALLENGES OF HIGHER EDUCATION IN GROWING DIALOGUE CULTURE AND UNDERSTANDING CULTURAL PLURALISM
}

\author{
Desmond Obasa $^{1} \&$ Jumoke Adebule ${ }^{2}$ \\ Logos State University, Nigeria \\ ${ }^{2}$ ContributorEmail: jbule@dutchmail.com
}

Received: June 25, 2017

Accepted: Aug 12, 2017

Published: Sept 28, 2017

Article Url: http://journal.scadindependent.org/index.php/jipeuradeun/article/view/183

\begin{abstract}
The contemporary world is increasingly multicultural and the identity crisis resulting from this sometimes threatens sustainable human development. Nigeria is a plural society in terms of its multi-ethnic and multi-religious nature. Of all the federal democracies in the world, only India can match Nigeria's cultural complexity. If well managed, this factor of unity in diversity would have been a major asset to the Nigerian state, but the contrary is the case. Nigeria's cultural diversity is politicized and exploited by the elite in such a way that retards the nation's growth and progress. This makes the promotion of understanding and dialogue to be a prime issue in the management of multiculturalism, global peace and security. This paper attempts to answer these questions by taking a critical look at the situations in Nigeria - one of the most culturally-complex countries in the world. The paper is divided into three parts. In the last part, which is actually the fulcrum of the presentation, the point is made that these challenges notwithstanding; the Nigerian universities still manage to make some outstanding contributions in the direction of promoting dialogue among the contending forces in the country. The Nigerian case study is internationally instructive.
\end{abstract}

Keywords: Higher Education, Culture, Dialogue, Nigeria 


\section{A. Introduction}

Nigeria is a plural society in terms of its multi-ethnic and multireligious nature. The country has more than 400 ethnic groups (Suberu 1998:277) and two major religions (Islam and Christianity). Of all the federal democracies in the world, only India can match Nigeria's cultural complexity (Joseph 2006:15). If well managed, this factor of unity in diversity would have been a major asset to the Nigerian state, but the contrary is the case.

Nigeria's cultural diversity is politicized and exploited by the elite in such a way that retards the nation's growth and progress. The problem affects all aspects of Nigeria's national life - federal and even local resource allocation, management of public institutions (Dudley 1973; Egwu 1993; Ake 1996: Anber 1967), and youth development (Babawale 2003; Akinyele 2001). The problem has fueled several bloody clashes between ethnic neighbours across the country (see Albert 1993; Otite and Albert 1999; Uwazie, Albert, and Uzoigwe 1991: Albert 2001), destabilized the country most especially at national level (Nnoli 1978; Mustapha 2002, 2004) and even produced a civil war (1967 to 1970) (Nafziger 1983).

The most threatening of the problems faced by the country is ethnicity. Osaghae defined the concept as "the employment or mobilization of ethnic identity and difference to gain advantage in situations of competition, conflict or cooperation" (Osaghae 1995:11). This definition challenges the position of the primordialists who argue that ethnicity is so much a matter of "shared traits or cultural commonalities". It is rather the result of the interplay between external categorization and self-identification (Brubaker, Loveman and Stamatov 2004:31-32).

In other words, the problem of ethnicity in Nigeria is easier understood in terms of the competition between the ethnic groups in the country for the scarce resources available to the federation. The second point that seemed to have been underscored by Osaghae's definition is that ethnicity could affect any aspect of a society: most especially the ownership and management of national resources. In a related work, van den Berghe (1973) argued that public institutions in multi-ethnic and 
multi-religious societies are usually micro-political systems and this could place heavy burdens on their management.

At national level, the ethnic conflicts in Nigeria are largely among the three dominant groups in the country: the Hausa/Fulani, Yoruba and Igbo. At local level, the conflicts are between ethnic neighbours and these vary from one State to the other. At each of the locations, groups compete for the available economic, material and political resources and institutions and these are often done in a manner that threatens national peace and stability.

\section{B. Effect on Higher Education}

The national crisis negatively affects higher education in terms of how ethnic groups compete, sometimes acrimoniously, for the location and management of Federal Universities, Polytechnics, Colleges of Education and Colleges of Agriculture. The university system is one of the most contested by the contending groups in the country.

The aggressive competition between the diverse groups in Nigeria for the control of the universities derives from the assumption that these institutions have significant roles to play in elite formation and recruitment in addition to the fact that the institutions generate local employment and economic regeneration. Within this framework, ethnic and sub-ethnic groups in the country are sensitive to the location of universities, appointment of their Vice Chancellors, staff recruitment as well as admission of students. In most cases, the people of the States and communities where the Federal and State universities are located see the institutions as their personal property and would want them managed as such.

The most controversial is the appointment of Vice Chancellors. Ethnic groups in Nigeria come together to "fight" one another once a new Vice Chancellor is to be appointed. There are several cases of this type of problem in the country. Vice Chancellors are also under pressure when staff and students of the universities are to be recruited and admitted respectively.

It is interesting to note that many of these conflicts over vacant Vice Chancellorship positions started to occur in the late 1990s when the issue of 
ethnicity and religious fundamentalism became a critical factor in Nigerian politics (Uwazie, Albert and Uzoigwe 1999). As groups fight among themselves over religious issues, land ownership and the need to reform the Nigerian state generally, they politicize the questions of who should head the universities, how staff should be recruited and how students should be admitted. Most of the Vice Chancellors that were appointed before this period served outside their States of origin and did well. The list include Professor Akinkugbe, a Yoruba man, who served as the Vice Chancellor of the Ahmadu Bello University, a Hausa-Fulani enclave; Professor Adamu Baikie, a Hausa-Fulani who served successfully as the VC of the University of Benin and even got a second term; Professor J. Ezeilo, an Igbo and Christian who served as the Vice Chancellor of the Bayero University in Kano, a centre of Islamic civilization; Professor Essien-Udom, an Ibibio was at the University of Maiduguri, the Kanuri heartland; Professor Tekena Tamuno, an Ijaw, served as the VC of the University of Ibadan; Professor Onwuemechili, an Igbo, was at the University of Ife as the VC, and Professor Ayandele, a Yoruba, served as the VC of the University of Calabar.

\section{Culture of Dialogue and Tolerance}

The foregoing makes the need for fostering the culture of dialogue and understanding a major national project for Nigeria. What is "dialogue" and how do we want it applied to the issue of Nigeria's multiculturalism? Dialogue, as a social science concept, derives from two Greek words "dia" and "logos". "Dia" means "through' or "with each other" while "logos" means "the word". To this end, the word dialogue is etymologically understood to mean a free flow of information or meaning between people. In a multicultural society, it refers to an organic exchange information between and amongst peoples of diverse ethnic or religious orientations in such a way that helps to break down stereotypes and poor understanding of how others think or perceive the world around them (Weimann 2014: 19).

The significance of dialogue in this respect is embedded in the fact that poor communication is a major cause of identity conflict around the world. Explaining how this type of conflict crystallizes, Weimann argued that: 
Our interpretation of the message we have received from another person, as well as the decoding of the message, depends on our knowledge of this person. But, if the reality in which the message was formulated or encoded is too different from the reality it is interpreted in, or decoded, then the message received will not resemble the message emitted (Weimann 2014:23).

A Nigerian example suffices to support the above position. It has been clearly established at various meetings of the Nigeria Inter-religious Council (NIREC) which I coordinate that the major cause of religious crisis in Nigeria is that many adherents of the two major religions in the country - Islam and Christianity - do not have sufficient information on what each other's religion preaches. The Muslims are poorly educated about Christianity and the Christians are poorly educated about Islam. The reason is that there is limited opportunity for exchange of information between the adherents of the two religions. NIREC was established to deal with this problem.

Dialogue is a collaborative exercise; it requires the readiness of the interacting social actors. It is also voluntary; it cannot be forced on anybody. It requires trust, sincerity, and the willingness to accept diversity in human nature. It entails collective reflections, learning and communication between groups and a tolerance of paradox (or opposing views), the suspension of judgment and empathic listening. Its main goal is to promote societal cohesion by making complex issues to be collectively explored (Isaacs 1993; McGinn 2004).

\section{Dialogue and the Nigerian University System}

Dialogue in the context of higher education in Nigeria refers to two main situations: (i) the extent to which Nigerian universities are able to facilitate a healthy interaction among Nigerians most especially through capacity building (ii) the extent to which the university campus could be said to be a locus of intercultural exchange. The achievability of these two objectives is much dependent on the extent to which the government (most especially the Federal Government) is able to deal with the problem of identity crisis at national level. This is because, as said earlier, the problems come from the top. 
It is thus compelling for us at this point to examine a number of federal policies that promote the culture of dialogue, understanding and tolerance to the extent of having powerful impact on the functioning of the university system in Nigeria. The first of such policies is contained in Section 14, subsection 3 of the 1979 Constitution which provides as follows:

The composition of the Government of the Federation or any of its agencies and the conduct of its affairs shall be carried out in such a manner as to reflect the federal character of Nigeria and the need to promote national unity, and also to command national loyalty, thereby ensuring that there shall be no predominance of persons from a few states or combination of a few ethnic or other sectional groups in that Government or any of its agencies.

Section 277, sub-section 1 of the 1979 Constitution defined "federal character of Nigeria" as "the distinctive desire of the people of Nigeria to promote national unity, foster national unity and give every Nigerian a sense of belonging to the nation as expressed in Section 14(3) and 4 of this Constitution".

Since 1979, the federal character principle and others deriving from it (e.g. Section 157, sub-section 5; Section 197, sub-section 2; Section 199) have provided the basis for location of universities, polytechnics, Colleges of Education and even Federal Secondary Schools (High Schools) in Nigeria as well as the personnel to man these institutions. This policy is aimed at promoting equity in the Nigerian society and making all Nigerians to have a sense of belonging. A body known as the Federal Character Commission has been established by the Federal Government to promote, enforce and monitor compliance with provisions of the Federal Character Clauses of the Nigerian Constitution.

It is necessary to note however that unlike what obtains in Lebanon, Belgium, Cyprus, India and Malaysia where comparable constitutional provisions and public policy exist, the Nigerian Constitution does not reserve or earmark any quotas for any designated ethnic groups. Thus, each group in the federation adopts its own peculiar self-help strategies to get what it considers to be its own fair share of the "Nigerian national cake". The end product is widespread suspicion among groups and sub-groups in the country and this makes dialogue and understanding to be highly expedient at the 
national, state and communal levels but difficult to attain in the country. Higher education has significant roles to play in dealing with this problem.

Additionally, the Revised National Policy on Education which came into effect in 1981 specified that the growth and development of the university system in the country should ensure (a) " a more even geographical distribution (of universities) to provide a fairer spread of higher education facilities" in the country and that (b) "admission of students and recruitment of staff into universities and other institutions of higher learning should be on a broad national basis" (FGN cited in Yoloye 1989:75). This policy, in my consideration, is merely calling attention once again to the need to reflect "federal character". Ethnic and religious politics have made this policy a source of conflicts in many Nigerian universities today.

The Nigerian state also has a system for promoting dialogue and understanding on issues relating to students admission into federal universities. The prevailing regulation for the admission of students into the federal universities in the country was set out in a circular (Ref. No. FME/S/518/Vol. $1 / 99$ of Sept. 2, 1983) in which all universities in the countries are enjoined to promote diversity in their admission policies. Similarly, the Association of American Universities (AAU), consisting of 62 leading North American research universities, adopted a statement on April 14, 1997 that expresses strong support for continued attention to diversity in university admissions. The US diversity scheme takes into account a wide range of considerations - including ethnicity, race, and gender (AAU 1997). The AAU statement, which is significant for putting the Nigerian policy in global perspective, provided the following as the rationale for the diversity policy:

We believe that our students benefit significantly from education that takes place within a diverse setting. In the course of their university education, our students encounter and learn from others who have backgrounds and characteristics very different from their own. As we seek to prepare students for life in the twenty-first century, the educational value of such encounters will become very important, not less, than in the past.

A very substantial portion of our curriculum is enhanced by the discourse made possible by the heterogeneous backgrounds of our 
students. Equally, a significant part of education in our institutions takes place outside the classroom, in extracurricular activities where students learn how to work together, as well as to compete; how to exercise leadership, as well as to build their consensus. If our institutional capacity to bring together a genuinely diverse group of students is removed - or severely reduced - then the quality and texture of the education we provide will be significantly reduced... In this respect, we speak not only as educators, but also as concerned citizens. As presidents and chancellors of universities that have historically produced many of America's leaders in business, government, the professions, and the arts, we are conscious of our obligation to educate exceptional people who will serve all of the nation's different communities.

The US statement on diversity admission contained a statement that requires that we shed more light on the equivalent policy in Nigeria. The AAU statement noted: "We do not advocate admitting students who cannot meet the criteria for admission to our universities. We do not endorse quota or "set asides" in admissions. But we do insist that we must be able, as educators, to select those students - from among many qualified applicants - who will best enable our institutions to fulfill their broad educational purposes".

The Nigerian admission policy favours what the AAU refers to pejoratively as "quota" or "set asides". However, the policy is not to compromise meritocracy but rather provide opportunities for the best candidates from all regions of the country to be provided access to university education. The first regulation is that all students to be admitted must have met the minimum standards of the affected universities.

The following admission criteria were provided in the Nigerian circular mentioned above: (a) Merit - 40 percent (b) Catchment/Locality area - 30 percent (c) Educationally Less Developed States -20 percent (d) others - 10 percent. In other words if 100 students are to be admitted, the first best 40 are admitted first, the next 30 best are admitted from the locality and catchment areas, the next best 30 are admitted from the States of the federation considered to be educationally less developed, and the 
university bases the rest 10 admissions on any criteria considered best. In all, the 100 students admitted are among the best qualified candidates. No admission is given to any unqualified students.

There is the need to throw more light on the admission criteria. "Merit" as used above is determined by each candidate's score in the competitive examination conducted by the Joint Admissions Matriculation Board (JAMB) or the Advanced Level Certificate Examination conducted by the West African Examinations Council, the University of London and other related examination bodies. Under this criterion, the higher the score of a candidate, the higher the chances of his/her being admitted. "Catchment Area or Locality" is determined on the basis of states contiguous to the states in which each federal university is located. The "Educationally Less Developed States" are the later starters in western education. Candidates from these states are given special concession in the admission policy to enable them catch up with their counterparts from the more advanced states. Most of these states are from northern Nigeria. "Discretion" is used to admit students who could not be admitted based on the three earlier criteria but who in the opinion of the administrators of the concerned university deserve to be given consideration usually on humanitarian grounds (Yoloye 1989:65-68).

\section{E. The Role of Higher Education in Promoting Dialogue and Understanding}

The federal character policy in the appointment of Vice Chancellors and staff of the universities as well as in the admission of students has a positive impact on the promotion of a culture of dialogue, understanding and tolerance in Nigeria. It makes every Nigerian university to be a microsm of the Nigerian society in terms of generous mixture of all the ethnic and religious groups. Students from different parts of the country are thus forced to live side by side in the hostels; they do class assignments together and discuss the problems of Nigeria together. By the time many of these students return to their communities, they are different species of Nigerians altogether having towered above those ethnic and religious stereotypes that bedevil the Nigerian society and retard the growth of the country. Staff members go through the same 
experience. Their neighbors in the office, as a result of the Federal Character policy, are from other parts of Nigeria. Through the gossips and discussions of national issues in the office, they too are forced to understand the other groups in the country and to learn to work harmoniously with them.

The committee system in the university, Senate traditions and the wide ethnic and religious distribution of the teaching staff and principal officers of the university also constrain any Vice Chancellor from being sectional in his or her admission. He or she has to consult very widely and get the approval of appropriate bodies for all the steps that he or she takes. A good Vice Chancellor, under the present system in Nigeria, cannot afford not to be a good social mixer. He is daily invited by his staff and even students to naming ceremonies, funeral rites and other social functions that could in some cases offend his beliefs. He must demonstrate tolerance and understanding by attending many of these social functions.

The Higher Education in Nigeria, like their counterparts elsewhere, have three important mandates: to produce high-quality manpower for promoting national and international development; to carry out cutting-edge research; and to engage in community service. Issues pertaining to "fostering dialogue and understanding" point in the direction of the "community service" responsibility of the university. The fact remains, however, that in the process of teaching and doing research, universities equally promote dialogue and understanding. Some intervention projects of Nigerian universities can be used to shed more light on this.

\section{F. Conclusion}

The point made in this paper is that the Nigerian society is divided by the factors of ethnicity and religion and this works against the smooth running of the universities in the country most especially in terms of staff appointment, management of the institutions and recruitment of students into them. All these limit the extent to which the university system in the country could effectively foster the culture of dialogue and understanding. The paper defined the nature of this problem but 
attempted to underscore some modest efforts that some universities are making to still reach out to the people most especially in terms of making significant contributions to peacebuilding in the country.

The point was made in the presentation that the universities are merely a microsm of the larger Nigerian society and, within this framework, it is argued that the problems of ethnicity and religiosity in them would not go away until these two problems are played down at national level through the institutionalization of the policy of true federalism and a culture of tolerance most especially by the elite who exploit ethnicity and religiosity for personal gains. This does not mean that the universities themselves cannot solve the problems besetting them through in-house activities. These include the need for VCs to begin to see themselves as not representing any particular ethnic or religious groups as it often happens but as being the "fathers of all".

The management of the universities must place emphasis on meritocracy rather than mediocrity. This would make both staff and students to begin to see their future as being a function of how hardworking they are rather than a matter of sycophancy tied to ethnicity and religiosity. Universities must also organize regular seminars, workshops and conferences that build bridges across ethnic and religious divides. The lesson of the peace studies programmes at the Universities of Ibadan and Ilorin is that universities can silently contribute to the fostering of dialogue and understanding by training quality manpower for these activities at the grassroots level.

\section{Bibliography}

AAU (1997), "AAU Statement on the importance of diversity in university admissions", Washington, CD: The Association of American Universities.

Adekanye, B. (1983), "“Federal character" provisions of the 1979 constitution and the composition of the Nigerian armed forces", Plural Societies, Vol. 14.

Ake, C. (1996) "The political question", in: O. Oyediran (Ed.) Governance and Development in Nigeria: Essays in Honour Billy Dudley, Ibadan: Agbo Areo. 
Akinyele, R.T. (2001) "Ethnic Militancy and National stability in Nigeria: A Case Study of the Oodua People's Congress", African Affairs, Vol.100: 623-640

Albert, I. O. (1993) Inter-Ethnic Relations in a Nigerian City: a Historical Perspective of the Hausa-Igbo Conflicts in Kano 1953-1991, Ibadan: IFRA

Albert, I.O. (ed. 2001), Building Peace, Advancing Democracy: Third Party Intervention in Nigeria's Conflicts, Ibadan: PETRAF/John Archers Books.

Albert, I.O. (2005), “Terror as a political weapon: Reflections on the bomb explosions in Abacha's Nigeria", IFRA Special Research Issue, Volume 1 pp. 37-56.

Albert, I.O. (2005b), "General introduction", in I.O. Albert (ed.), Perspectives on Peace and Conflict in Africa: Essays in Honour of General (Dr.) Abdulsalami Abubakar, Ibadan: Peace and Conflict Studies Programme, University of Ibadan.

Albert, O. Mrs. (2009), "An assessment of the NUC policy on the teaching of Peace Studies as a GES course", Ph.D thesis submitted to the University of Ibadan, June 2009.

Anber, P. (1967) "Modernization and Political Disintegration: Nigeria and the Ibos", The Journal of Modern African Studies, Vol. 5 (5): 163-179

Dudley, B. J. (1973) Instability and Political Order: Politics and Crisis in Nigeria, Ibadan: University Press Ltd

Egwu, S (1993) "Ethnicity, Economic Crisis and National Development in Nigeria" in O. Nnoli ed. Dead-end to Nigerian Development: An Investigation on the Social Economic and Political Crisis in Nigeria, Dakar: CODESRIA Book Series: 44-78

Isaacs, W. (1993), "Dialogue: the power of collective thinking", The systems thinker, April.

Jinadu, L.A (1985), "Federalism, the consociational state and ethnic conflict in Nigeria", PUBLIUS: The Journal of Federalism, Vol. 15 pp.71 - 100.

Jinadu, L. A. (2012). Ethnic conflict and federalism in Nigeria. ZEFDiscussion Papers on Development Policy. Bonn, Germany: Center for Development Research. 
Jinadu, L.A. (2016), “Nigerian university and the problem of cultural diversity: policy responses and consequences", in W.R. Allen, M. Bonous-Hammark and R.T. Teranishi (eds.), Higher Education in a global society: Achieving diversity, equity and excellence, Advances in Education in Diverse Communities: Research, Policy and Praxis, Volume 5 pp. 7-32.

Joseph, R. (2016), "Mis-governance and the African predicament: Can the code be broken", Faculty Distinguished Personality Lecture Series 1, Delivered 30November, Faculty of the Social Sciences, University of Ibadan.

Materu, P. (2007), Higher education quality assurance in sub-Saharan Africa: Status, challenges, opportunities, and promising practices, New York: The World Bank.

McGinn, N.F. (2004), “An argument for dialogue in definition of national policies for education", Journal of International Cooperation, Volume 7 No. 1 pp. 15-25.

Mustapha, A. R. (2012) Ethnicity and democratization in Nigeria, in D. Eyoh, B. Berman \&W. Kymlicka (eds) Ethnicity and Democracy in Africa, Oxford: James Currey.

Mustapha, A. R. (2014) “Nigeria: Ethnic Structure, Governance and Public Sector Reform", paper presented at UNRISD Conference on Ethnic Structure, Governance and Public Sector Reform, March 2014.

Nafziger, E. W. (1983) The Economics of Political Instability: The NigerianBiafran War, Boulder CO: Westview Press

Nnoli, O. (1978) Ethnic Politics in Nigeria, Enugu: Fourth Dimension Publishers.

Nnekwu, D.A. (2007), "A Comparative Survey of the Impact of Ethnicity and Religious Affiliation on the Alienation of Staff from their Work Environment in Nigerian Universities", Research in Education, Volume 78 pp. $35-53$

Otite, O. (1990), Ethnic pluralism and ethnicity in Nigeria, Ibadan, Nigeria: Safari Books

Otite, O. and I. O. Albert (eds.) Community Conflicts in Nigeria: management, Resolution and Transformation, Ibadan: Spectrum Books 
Suberu, T.R. (1998), "States creation and the political economy of Nigerian federalism", in Kunle Amuwo et al (eds.), Federalism and political restructuring in Nigeria, Ibadan: Spectrum Books Limited.

Uwazie, E. U., Albert, I.O and Uzoigwe, G.N. (eds.), Inter-Ethnic and Religious Conflict Resolution in Nigeria, Lanham, Maryland: Lexington Books, 1999.

Weimann, G. (2014), “Openness to dialogue and the limits of intercultural dialogue", in Conflict: What has religion go to do with it?, Accra: Woeli Publishing Services.

Yoloye, F.A. (1989), "Federal character and institutions of higher learning", In P. Ekeh and E. Osaghae (eds.), Federal Character and Federalism in Nigeria, Ibadan: Heinemann Educational Books (Nigeria) Limited, pp. 47-49. 